\title{
DRUG-INDUCED PHOTOSENSITIVITY - A CONTINUING DIAGNOSTIC CHALLENGE
}

\author{
Liborija Lugović-Mihić, Tomislav Duvančić, Iva Ferček, Petra Vuković, \\ Iva Japundžić and Diana Ćesić
}

Clinical Department of Dermatovenereology, Sestre milosrdnice University Hospital Center, Zagreb, Croatia

\begin{abstract}
SUMMARY - When taking different drugs, their possible side effects on the skin should be considered, including skin reactions connected to photosensitivity. This photosensitivity caused by drugs can appear as phototoxic reactions (which occur more often) or photoallergic reactions (which occur less often and include allergic mechanisms). The following drugs stand out as medications with a high photosensitivity potential: nonsteroidal anti-inflammatory drugs (NSAIDs), cardiovascular drugs (such as amiodarone), phenothiazines (especially chlorpromazine), retinoids, antibiotics (sulfonamides, tetracyclines, especially demeclocycline and quinolones), etc. In recent years, photosensitive reactions to newer drugs have appeared, e.g., targeted anticancer therapies such as BRAF kinase inhibitors (vemurafenib, dabrafenib), EGFR inhibitors, VEGFR inhibitors, MEK inhibitors, Bcr-Abl tyrosine kinase inhibitors, etc. In patients taking drugs over a longer period of time (e.g., NSAIDs, cardiovascular drugs, etc.), a particular problem arises when an unrecognized drug-induced photosensitivity on the skin manifests in summer months. When taking patient histories, the physician/dermatovenereologist should bear in mind that any drug the patient is currently taking may be the cause of skin reactions. Therefore, patients who use potentially photosensitive drugs and treatments on a long term basis should be warned of the possibility of these side effects on their skin and advised to avoid direct exposure to sunlight and to use adequate photoprotection. If patients carefully protect themselves from the sun, it is often not necessary to stop treatments that include photosensitive drugs. If such reactions appear, anti-inflammatory and antiallergic therapies should be introduced.
\end{abstract}

Key words: Drug-related side effects and adverse reactions; Photosensitivity disorders; Dermatitis, phototoxic - therapy; Dermatitis, photoallergic - therapy

\section{Introduction}

Drug-induced photosensitivity is only one form in the line of medical eruptions, and indicates the occurrence of skin lesions caused by simultaneous influence of medication and exposure to light ${ }^{1-7}$. In the past few decades, photosensitivity has been reported with an array of drugs, and is now recognized as a noteworthy medical problem ${ }^{8}$.

Correspondence to: Prof. Liborija Lugović-Mibic, MD, PhD, Clinical Department of Dermatovenereology, Sestre milosrdnice University Hospital Center, Vinogradska c. 29, HR-10000 Zagreb, Croatia

E-mail: liborija@gmail.com

Received October 20, 2016, accepted February 7, 2017
Photosensitive skin reactions can be the consequence of topical or systemic use of the drug, where phototoxic or photoallergic reactions can occur as a side effect ${ }^{8-11}$. Thus, several hundred drugs or substances may provoke phototoxic and photoallergic reactions and the list of those medications has expanded in the last five years ${ }^{8,12}$.

Phototoxic reactions become visible very soon upon exposure to the accountable agent (within a few minutes or hours), whereas photoallergic agent visibility appears slowly (within one or three days after contact with the body) ${ }^{7,9}$.

Photosensitivity includes a number of interactions and photochemical reactions ${ }^{8}$. Thereby, the mechanism of drug-induced photosensitivity refers to the devel- 
opment of interaction between a chemical agent and light, while a photosensitive agent reacts to harmless UV radiation ${ }^{9-11}$. These reactions to drugs are mostly stimulated by action spectrum within the UVA (320$400 \mathrm{~nm}$ ) and visible light range or sometimes UVB (290-320 nm) range. Phototoxic reactions are frequent and can occur in the majority of individuals given large enough dose of phototoxic drug while being exposed to enough light. These reactions can be caused by any of these drugs used orally, topically (e.g., creams, fragrances, soaps, etc.), or injected. There are many potential drugs and exogenous agents causing photosensitivity reactions, such as nonsteroidal anti-inflammatory drugs (NSAIDs), antiarrhythmics, antihypertensives, neuroleptic drugs, antibiotics, retinoids, etc. ${ }^{4,9,10,13}$. Generally, the main systemic drugs inducing photosensitivity are NSAIDs, antimicrobials, and cardiovascular drugs, whereas the main topical agents that cause contact photosensitivity are NSAIDs ${ }^{1}$. Clinically, phototoxic and photoallergic reactions occur in the sunexposed areas of the skin, including the face, neck, hands and forearms, where various skin lesions can appear (Figs. 1 and 2).

Although similar in clinical picture, phototoxic and photoallergic skin reactions have few distinguishing characteristics $^{9-11}$. Phototoxic disorders have a high incidence, whereas photoallergic reactions are much less frequent in the human population. In phototoxic reactions, the amount of agent required for photosensitivity is large and the mechanism does not include immune reactions but light-activated cell membrane compounds and DNA. On the other hand, in photoallergic reactions, the amount of agent required for photosensitivity is small and the mechanism includes cellmediated immune responses (type IV) to a light-activated compound ${ }^{9,14}$. In phototoxic reaction, distribution includes only sun-exposed skin and clinical characteristics are similar to exaggerated sunburn, whereas photoallergic reaction includes dermatitis (systemic administration of photo-allergen causes a picture of drug eruption, while topical application of the substance causes eczematous morphology $)^{4-10}$. Generally, drug-induced photosensitivity reactions can occur in persons of any age. There are data showing that skin reactions to drugs appear in the form of photosensitive eruption in $8 \%$ of cases $^{15}$. Generally, photoallergic reactions are more common in men than in women. Phototoxic reactions to a drug or treatment, in combination with sunlight, involve a complex patho- genic mechanism. In phototoxic reactions to photosensitive drugs or substances, energy from UV radiation is absorbed by the molecules of phototoxic agents, resulting in the formation of substances such as free radicals and others which can cause toxic cell damage, resulting in skin cell death. Phototoxic dermatitis includes a complex mechanism of cell damage and comprises a complex of different reactions ${ }^{9}$. Thereby, photoactivation of a compound results in the activation of electrons (from the stable singlet state to an excited triplet state), which then return to a more stable configuration and transfer their energy to oxygen. Thus, reactive oxygen intermediates (e.g., singlet oxygen, superoxide anions, and hydrogen peroxide) damage cell membranes and DNA. This includes the signal transduction pathways and production of proinflammatory cytokines and arachidonic acid metabolites, resulting in skin inflammatory response ${ }^{4,9}$. Clinically, phototoxic lesions on the skin are usually noticed relatively quickly (within 5-20 hours from exposure) by lesions in the sun-exposed areas, with erythema, edemas, blisters, exudates and desquamation, followed by the possible additional delay of hyperpigmentation (Figs. 1 and 2).

On the other hand, photoallergic reactions develop only in a minority of individuals exposed to the combination of a compound (mostly systemic drugs) and UV light ${ }^{6-9}$. The amount of drug required to elicit photoallergic reactions is considerably smaller than that required for phototoxic reactions. In photoallergic reactions to drugs influenced by UV radiation, there is a change of the molecule form into a new matter, causing response of the immune system and it can extend to all parts of the body. In doing so, UV energy causes binding of the drug as a hapten to proteins in epidermal cells, creating an antigen which synthesizes lymphocytes in the vicinity; all this occurs in the predisposed and previously sensitized person (type IV reaction $)^{9,14}$. Reactions in a sensitized person can occur after repeated exposure to the drug and sunlight and are manifested in the skin some time later than phototoxic reactions (beginning within 24-72 hours after exposure to drug and light).

Clinically, photoallergic reactions to a drug usually manifest as a pruritic eczematous eruption, and in the acute phase there is erythema and vesicles, while more chronic exposure results in erythema, lichenification and scaling ${ }^{7-10,15}$. Opposed to phototoxic reactions, photoallergic skin lesions can also spread out of the sunexposed area, and hyperpigmentation does not occur. 


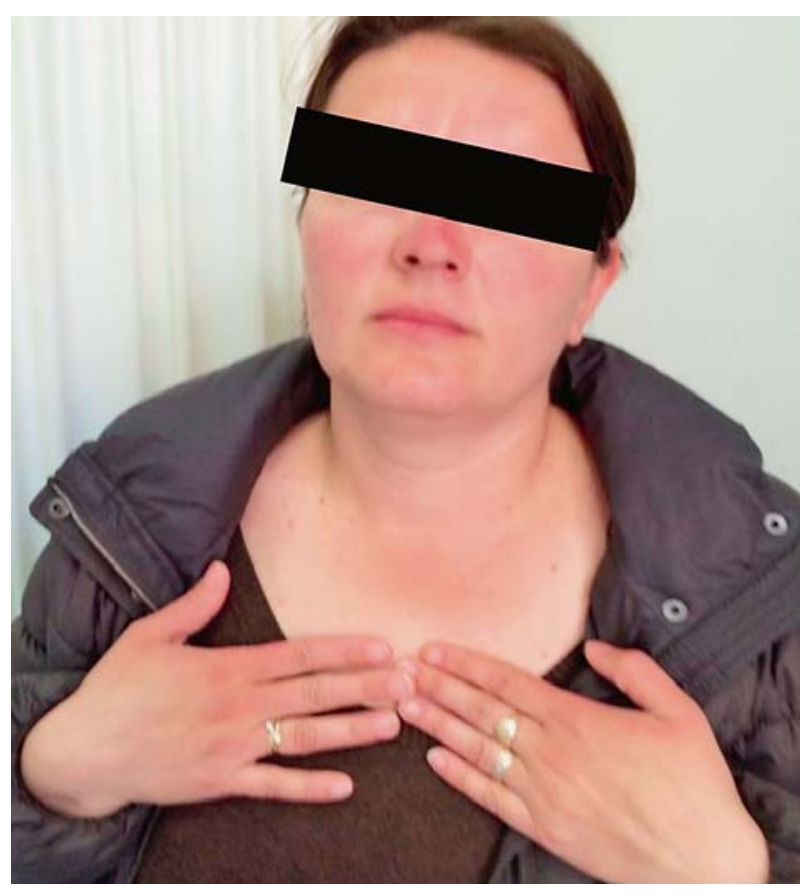

Fig. 1. Phototoxic reaction caused by doxycycline.

Phototoxic effects of the drugs can also be used for therapeutic purposes, e.g., application of a photosensitizer such as psoralen and aminolevulinic acid. Thus, psoralen and ultraviolet light therapy (UVA) are combined as a type of phototherapy (PUVA), which is used to treat different skin diseases. Thereby, psoralen makes the skin more sensitive to UV light where psoralens intercalate within DNA. Thus, monofunctional adducts are formed, and after exposure to UVA radiation, bifunctional adducts within DNA appear, although it is still not known how bifunctional adducts cause photosensitivity ${ }^{9}$. Also, photodynamic therapy (PDT) is a treatment which also uses photosensitizing agents (e.g., topical aminolevulinic acid). The phototoxic effect of the agents may cause skin lesions (e.g., actinic keratoses) to disappear or decrease in size ${ }^{12}$.

In addition, drugs with potential photosensitivity may have other skin manifestations, for example, porphyria (e.g., liver damage by oral contraceptives) or lupus erythematosus (e.g., hydralazine).

\section{Drugs and Substances Associated with Sensitivity to the Sun}

It is noticeable that drugs and substances have different potential for causing skin photosensitivity. The

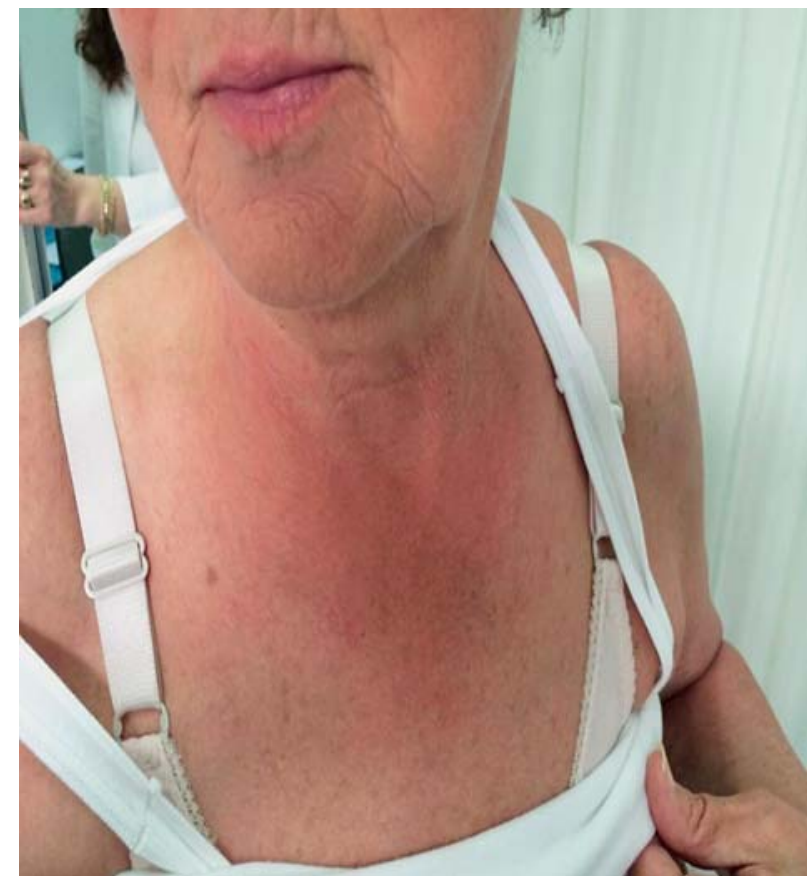

Fig. 2. Phototoxic reaction caused by antihypertensive drug.

drugs which are often associated with photosensitivity reactions are NSAIDs (e.g., ibuprofen, ketoprofen, piroxicam, diclofenac), cardiovascular drugs (furosemide, amiodarone, thiazides), antibiotics (tetracyclines, ciprofloxacin, sulfonamides), psoralens, neuroleptic drugs such as phenothiazines (especially chlorpromazine), oral contraceptives, retinoids (isotretinoin, acitretin), antifungals, etc.,3,9,16,17. Several antibiotics and related drugs are associated with photosensitive reactions, e.g., amoxicillin, ciprofloxacin, clofazimine, dapsone, demeclocycline, doxycycline, enoxacin, flucytosine, griseofulvin, lomefloxacin, minocycline, nalidixic acid, norfloxacin, ofloxacin, oxyfloxacin, oxytetracycline, pyrazinamide, sulfonamide, tetracycline, trimethoprim, etc. ${ }^{9,15-17}$.

In general, it is noted that photosensitive reactions are often induced by compounds with halogen elements (amiodarone, chlorpromazine, fluoroquinolones, chloroquine, hydrochlorothiazide, etc.). Amiodarone (antiarrhythmic) is especially connected to the common incidence of photosensitivity reactions, depending on therapy dose and duration. Usually, symptoms develop within two hours of sun exposure in the form of burning sensation and erythema, and sometimes occur as graphite-gray pigmentation in sun-exposed areas. The incidence in the population of $\mathrm{pa}^{-}$ 
tients with prolonged use of amiodarone reaches nearly $75 \%$ according to various sources, but they are often misdiagnosed or overlooked ${ }^{18}$. After drug discontinuation, photosensitivity may last for up to another four months, with gradual fading of lesions over months to years. In most cases, these effects are reversible and disappear after discontinuation of the drug.

Photosensitive reactions are also commonly related to chlorpromazine (antipsychotic), particularly when administered in high doses, and can cause skin lesions like burning and painful erythema (appearing in a few minutes after exposure) which can last for more than 24 hours, and sometimes golden-yellow or graphitegray pigmentation may occur, mainly on sun-exposed $\operatorname{areas}^{15}$.

In recent years, photosensitive reactions have appeared with newer drugs such as targeted anticancer therapies, for example BRAF kinase inhibitor vemurafenib (observed in 31\%), dabrafenib, etc. ${ }^{19}$. Photosensitivity potential has also been reported with the use of epidermal growth factor receptor (EGFR) inhibitors, vascular endothelial growth factor (VEGF) receptor (VEGFR) inhibitors, mitogen-activating extracellular kinase (MEK) inhibitors, Bcr-Abl tyrosine kinase inhibitors, and other therapies such as chemotherapeutics ${ }^{19-22}$. In addition, photoreactions to biologics are also possible (e.g., tocilizumab) ${ }^{23}$.

Medications also differ in the frequency of phototoxic and photoallergic reactions. Some of the drugs more frequently cause phototoxic reaction (tetracyclines, sulfonamides, furosemide, isotretinoin, acitretin, etc.), whereas others are more likely to cause photoallergic reaction (hypoglycemic sulfonylureas, sunscreens, dapsone), and some have an equal potential to cause both types of reactions (ketoprofen, hydrochlorothiazide, phenothiazines, etc.).

Topical preparations may also provoke photosensitivity reactions. According to research data, the leading contact photosensitizers are sunscreens and topical NSAID $^{24}$. It is also necessary to consider photosensitivity when using cosmetics, sunscreens, herbal extracts, etc. ${ }^{25-29}$. Therefore, it is always necessary in practice to have in mind the possibility of reactions to topical drugs ${ }^{30}$.

Besides classic phototoxic and photoallergic reactions, some drugs may also cause a lichen planus-like eruption in sun-exposed areas, e.g., demeclocycline, hydrochlorothiazide, enalapril, quinine, quinidine, chloroquine, hydroxychloroquine, etc., ${ }^{9,31}$. Sometimes photosensitizing drugs may also cause pseudoporphyria (skin lesions similar to porphyria cutanea tarda), e.g., after exposure to naproxen, nalidixic acid, tetracycline, sulfonylureas, furosemide, dapsone, amiodarone, etc. ${ }^{16,32}$.

\section{Diagnosis and Therapy}

Drug-induced photosensitivity remains a common clinical problem and is often underdiagnosed ${ }^{1}$. In recognizing photosensitivity to a drug, most important are complete patient history and clinical appearance ${ }^{4-7}$. Patients who report photosensitivity should be asked about the medications they take and the products that are applied to their skin ${ }^{15}$.

In patients who take drugs over a longer period of time (e.g., NSAIDs, cardiovascular drugs, etc.), a particular problem occurs when an unrecognized druginduced photosensitivity manifests on the skin in summer months. Therefore, when taking patient history, the physician/dermatovenereologist should bear in mind that any drug the patient is currently taking could be the cause of skin reaction.

A clinical picture with the occurrence of skin lesions on sun-exposed areas, including the face, neck, hands and forearms, usually indicates potential photosensitivity which can be linked with the drug. Extended reaction usually indicates a systemic photosensitive agent, whereas localized reaction points to reaction to a topically applied photosensitizer 9 .

In diagnosing photosensitivity disorders, the most important procedure is photo-testing with UVA, UVB or sometimes visible light, performed by exposing small areas of the skin on the back or inner aspect of the forearms with gradually increasing doses of light. A positive reaction at the non-irradiated site with a stronger one at the irradiated site should be interpreted as both allergic dermatitis and photoallergic contact dermatitis reaction to the same compound.

The main investigative technique to diagnose photoallergic or phototoxic reactions is photopatch testing, although it is not commonly used ${ }^{24,33-35}$. However, to perform this kind of procedure, proper equipment is needed, which is often lacking. In the diagnosis of photoallergic contact dermatitis, photopatch testing is a crucial/important tool, performed by applying suspected photoallergens to the back in two sets, and subsequent reaction reading ${ }^{4,34,35}$. 
Currently available testing methods also include the photoprick, photoscratch and illuminated intracutaneous tests ${ }^{12}$. If the causative photosensitizer is not the test substance but a metabolite of the test substance, a systemic photoprovocation test can be utilized.

Skin biopsy of phototoxic reactions may also be performed, although is not very useful because it often shows nonspecific changes (epidermal spongiosis, dermal edema, mixed infiltrate of lymphocytes, macrophages, neutrophils, etc.), but sometimes shows necrotic keratinocytes in acute stage. On the other hand, blue-gray pigmentation is characteristic of phototoxic reactions resulting from increased melanin in the dermis or deposition of the drug or its metabolites in the $\operatorname{skin}^{4,9}$. Histopathologic analysis of photoallergic reactions also includes epidermal spongiosis and dermal lymphocytic infiltrate, with necrotic keratinocytes, which is suggestive of photoallergy.

Treatment of phototoxic and photoallergic dermatitis includes identification and avoidance of the offending drug, symptomatic measures, topical corticosteroids, cool dressings, antihistamines, and sometimes systemic corticosteroids ${ }^{9-11}$. In severe phototoxic reactions, the management may even include burn care units. Generally, patients are advised to use the sunscreens with UVA protection with high sun protection factor (SPF), but sunscreens could also be causative agents, since they often contain para-aminobenzoic acid, which can cause photosensitivity of the skin.

On the other hand, it is important to know that $\mathrm{SPF}$ is not a reliable indicator of protection against drug-induced photosensitivity and primarily refers to the degree of protection against the UVB range. $\mathrm{Pa}-$ tients with potentially photosensitive agents in long term therapy should be alerted to the problem and advised on proper protection. Such patients should avoid exposure to direct sunlight, wear protective clothing, and use a cream with high $\mathrm{SPF}^{4,5,15}$. In most cases of phototoxic eruptions, it is not necessary to stop drug therapy if sun protection is possible. However, in photoallergic reactions, the drug should be discontinued as soon as possible since the slightest sun exposure could cause serious reactions. If sun protection measures are applied on time, it is often not necessary to stop the treatments that include photosensitive drugs, but in the case that such reactions do show up, anti-inflammatory and antiallergic therapy should be introduced.
Although dermatological complications and photosensitivity usually do not influence the outcome of therapy and rarely cause discontinuation of treatment, they have great impact on the patient quality of life $\mathrm{e}^{18,36}$.

\section{Conclusion}

Patients who use potentially photosensitive drugs and treatments on long term basis should be warned of the possibility of these side effects on their skin, and should be advised to avoid direct exposure to sunlight, as well as to use appropriate photoprotection. In order to avoid photosensitive reactions, it is essential to know the photosensitizing properties of such drugs and to advise the patients. If sun protection measures are taken timely, it is often not necessary to stop treatments that include photosensitizing drugs. If such reactions do appear, anti-inflammatory and antiallergic therapies should be introduced.

\section{References}

1. Monteiro AF, Rato M, Martins C. Drug-induced photosensitivity: photoallergic and phototoxic reactions. Clin Dermatol. 2016;34(5):571-81. doi: 10.1016/j.clindermatol.2016.05.006. Epub 2016 May 20

2. Zuba EB, Koronowska S, Osmola-Mańkowska A, Jenerowicz D. Drug-induced photosensitivity. Acta Dermatovenerol Croat. 2016;24(1):55-64.

3. Zuba EB, Francuzik W, Malicki P, Osmola-Mańkowska A, Jenerowicz D. Knowledge about ultraviolet radiation hazards and tanning behavior of cosmetology and medical students. Acta Dermatovenerol Croat. 2016;24(1):73-7.

4. Gould JW, Mercurio MG, Elmets CA. Cutaneous photosensitivity diseases induced by exogenous agents. J Am Acad Dermatol. 1995;33:551-73.

5. González E, González S. Drug photosensitivity, idiopathic photodermatoses, and sunscreens. J Am Acad Dermatol. 1996; 35:871-85.

6. Lim HW. Abnormal responses to ultraviolet radiation: photosensitivity induced by exogenous agents. In: Wolff K, Goldsmith LA, Katz SI, et al. (eds.). Fitzpatrick's Dermatology in General Medicine. New York: McGraw-Hill, 2008. p. 828-50.

7. Victor FC, Cohen DE, Soter NA. A 20-year analysis of previous and emerging allergens that elicit photoallergic contact dermatitis. J Am Acad Dermatol. 2010;62:605-10. doi: 10.1016/j.jaad.2009.06.084. Epub 2010 Feb 16

8. Zaheer MR, Gupta A, Iqbal J, Zia Q, Ahmad A, Roohi, et al. Molecular mechanisms of drug photodegradation and photosensitization. Curr Pharm Des. 2016;22(7):768-82. 
9. Lehmann P. Photodermatoses. In: Burgdorf WHC, Plewig G, Wolff HH, Landthaler M, eds. In: Braun-Falco's Dermatology. $3^{\text {rd }}$ edition. Heidelberg: Springer, 2009. p. 573-97.

10. Allen JE. Drug-induced photosensitivity. Clin Pharm. 1993; 12(8):580-7.

11. Lugović L, Šitum M, Ožanić-Bulić S, Sjerobabski-Masnec I. Phototoxic and photoallergic skin reactions. Coll Antropol. 2007;31(Suppl 1):63-7.

12. Scheinfeld NS1, Chernoff K, Derek Ho MK, Liu YC. Druginduced photoallergic and phototoxic reactions - an update. Expert Opin Drug Saf. 2014;13(3):321-40. doi: 10.1517/ 14740338.2014.885948

13. Soldevila S, Cuquerella MC, Bosca F. Understanding of the photoallergic properties of fluoroquinolones: photoreactivity of lomefloxacin with amino acids and albumin. Chem Res Toxicol. 2014;27(4):514-23. doi: 10.1021/tx400377s. Epub 2014 Feb 26.

14. Bakula A, Lugović-Mihić L, Šitum M, Turčin J, Šinković A. Contact allergy in the mouth: diversity of clinical presentations and diagnosis of common allergens relevant to dental practice. Acta Clin Croat. 2011;50(4):553-61.

15. Goncalo M. Phototoxic and photoallergic reactions. In: Johansen JD, et al. (eds.). Contact Dermatitis. Berlin Heidelberg: Springer-Verlag, 2010. p. 1-13.

16. Racette AJ, Roenigk HH Jr, Hansen R, Mendelson D, Park A. Photoaging and phototoxicity from long-term voriconazole treatment in a 15-year-old girl. J Am Acad Dermatol. 2005;52(5 Suppl 1):81-5. doi: 10.1016/j.jaad.2004.07.034

17. Viola E, Coggiola Pittoni A, Drahos A, Moretti U, Conforti A. Photosensitivity with angiotensin II receptor blockers: a retrospective study using data from VigiBase ${ }^{\circledR}$. Drug Saf. 2015; 38(10):889-94. doi: 10.1007/s40264-015-0323-7

18. Jaworski K, Walecka I, Rudnicka L, Gnatowski M, Kosior DA. Cutaneous adverse reactions of amiodarone. Med Sci Monit. 2014;20:2369-72. doi: 10.12659/MSM.890881

19. Larkin J, Del Vecchio M, Ascierto PA, Krajsova I, Schachter J, Neyns B, et al. Vemurafenib in patients with BRAF(V600) mutated metastatic melanoma: an open-label, multicentre, safety study. Lancet Oncol. 2014;15(4):436-44. doi: 10.1016/S14702045(14)70051-8. Epub 2014 Feb 27

20. Goldstein J, Patel AB, Curry JL, Subbiah V, Piha-Paul S. Photoallergic reaction in a patient receiving vandetanib for metastatic follicular thyroid carcinoma: a case report. BMC Dermatol. 2015;15:2. doi: 10.1186/s12895-015-0022-1

21. Kamil N, Kamil S, Ahmed SP, Ashraf R, Khurram M, Ali MO. Toxic effects of multiple anticancer drugs on skin. Pak J Pharm Sci. 2010;23(1):7-14.

22. Belum VR, Washington C, Pratilas CA, Sibaud V, Boralevi F, Lacouture ME. Dermatologic adverse events in pediatric patients receiving targeted anticancer therapies: a pooled analysis.
Pediatr Blood Cancer. 2015;62(5):798-806. doi: 10.1002/ pbc.25429. Epub 2015 Feb 12

23. Hamada K, Sawada Y, Yamaguchi T, Ohmori S, Omoto D, Haruyama $S$, et al. Photosensitivity due to tocilizumab presenting with erythema multiforme-like lesions. Eur J Dermatol. 2016; 26(5):503-4. doi:10.1684/ejd.2016.2819

24. Honari G. Photoallergy. Rev Environ Health. 2014;29(3):23342. doi: 10.1515/reveh-2014-0067

25. Veraldi S, Brena M, Barbareschi M. Allergic contact dermatitis caused by topical antiacne drugs. Expert Rev Clin Pharmacol. 2015;8(4):377-81. doi: 10.1586/17512433.2015.1046839. Epub 2015 May 17.

26. Kawakami CM, Gaspar LR. Mangiferin and naringenin affect the photostability and phototoxicity of sunscreens containing avobenzone. J Photochem Photobiol B. 2015;151:239-47. doi: 10.1016/j.jphotobiol.2015.08.014. Epub 2015 Aug 15.

27. Murray J, Potts A. The phototoxic and photoallergy potential of clindamycin phosphate $1.2 \%$ /tretinoin $0.025 \%$ gel for facial acne: results of two single-center, evaluator-blinded, randomized, vehicle-controlled phase 1 studies in healthy volunteers. J Drugs Dermatol. 2014;13(1):16-22.

28. Benevenuto CG, Guerra LO, Gaspar LR. Combination of retinyl palmitate and UV-filters: phototoxic risk assessment based on photostability and in vitro and in vivo phototoxicity assays. Eur J Pharm Sci. 2015;68:127-36. doi: 10.1016/j.ejps.2014. 12.007. Epub 2014 Dec 19.

29. Nash JF1, Tanner PR. Relevance of UV filter/sunscreen product photostability to human safety. Photodermatol Photoimmunol Photomed. 2014;30(2-3):88-95. doi: 10.1111/phpp. 12113. Epub 2014 Feb 19

30. Saraf S, Gupta A, Kaur CD, Jangde M, Saraf S. Dermatological consequences of photosensitization with an approach to treat them naturally. Pak J Biol Sci. 2014 Jan 15;17(2):167-72.

31. Ellgehausen P, Elsner P, Burg G. Drug induced lichen planus. Clin Dermatol. 1998;16:325-32.

32. Hrabovsky SL, Elmets CA. Pathogenesis, characteristics, diagnosis and treatment of pseudoporphyria. Curr Opin Dermatol. 1996;3:105-10.

33. Wilm A, Berneburg M. Photoallergy. J Dtsch Dermatol Ges. 2015;13(1):7-12; quiz 13. doi: 10.1111/ddg. 12535

34. Zeeli T, David M, Trattner A. Photopatch tests: any news under the sun? Contact Dermatitis. 2006;55(5):305-7. doi: 10.1111/j.1600-0536.2006.00787.x

35. Rünger TM, Lehmann P, Neumann NJ, Matthies C, Schauder $\mathrm{S}$, Ortel B, et al. Recommendations for a photo-patch test standard series by the German speaking study group „PhotopatchTest“. Hautarzt. 1995;46(4):240-3.

36. Lugović-Mihić L, Ljubešić L, Mihić J, Vuković-Cvetković V, Šitum M. Psychoneuroimmunologic aspects of skin diseases. Acta Clin Croat. 2013;52(3):337-45. 
Sažetak

FOTOOSJETLJIVOST UZROKOVANA LIJEKOVIMA - KONTINUIRANI DIJAGNOSTIČKI IZAZOV

\section{Lugović-Mibić, T. Duvančić, I. Ferček, P. Vuković, I. Japundžić i D. Ćesić}

Prilikom uzimanja različitih lijekova moguće su nuspojave na koži, među kojima su i reakcije povezane s fotoosjetljivošću lijeka. Fotoosjetljivost uzrokovana lijekovima može se iskazati u obliku fototoksične reakcije (koje su češće) ili fotoalergijske reakcije (koje su rjeđe i uključuju alergijske mehanizme). Kao lijekovi s visokim fotoosjetljivim potencijalom ističu se amjodaron, nesteroidni antireumatici (NSAR), kardiovaskularni lijekovi (kao amjodaron), fenotiazini (osobito klorpromazin), retinoidi, antibiotici (sulfonamidi, tetraciklini, osobito dimeklociklin i kinoloni) itd. Posljednjih su godina reakcije fotoosjetljivosti zabilježene i na novije lijekove kao što je ciljana antitumorska terapija, npr. inhibitori BRAF kinaze (vemurafenib, dabrafenib), EGFR inhibitori, VEGFR inhibitori, MEK inhibitori, inhibitori Bcr-Abl tirozin kinaze itd. U bolesnika koji uzimaju lijekove tijekom dužeg razdoblja (npr. NSAR, kardiovaskularni lijekovi itd.) osobit problem je mogućnost neprepoznavanja lijekom potaknute kožne fotoosjetljivosti koja se javlja u ljetnim mjesecima. Stoga bi kod uzimanja anamneze bolesnika liječnik/dermatovenerolog trebao imati na umu da bilo koji lijek koji bolesnik uzima može biti uzrok kožnih promjena. Prema tome, bolesnike koji duže vrijeme uzimaju potencijalno fotoosjetljive lijekove i postupke treba upozoriti na mogućnost ovih nuspojava na koži te bi ih trebalo savjetovati da izbjegavaju izravno izlaganje sunčevu svjetlu i da primjenjuju mjere za zaštitu od sunčeve svjetlosti. Ako se na vrijeme započne s mjerama zaštite od sunca onda često nije potrebno prekidati liječenje koje uključuje fotoosjetljive lijekove. Ako se takve reakcije ipak pojave treba započeti protuupalnu i protualergijsku terapiju.

Ključne riječi: Uzimanje lijekova, popratni učinci i štetna djelovanja; Fotosenzitivni poremećaji; Dermatitis, fototoksični terapija; Dermatitis, fotoalergičn - terapija 